\title{
MORPHOLOGICAL ANALYSIS OF PERIPHERAL BLOOD CELLS OF Chelonoidis carbonaria (Spix, 1824)
}

\author{
ANÁLISE MORFOLÓGICA DAS CÉLULAS DO SANGUE PERIFÉRICO DE \\ Chelonoidis carbonaria (Spix, 1824)
}

\author{
Renata Patrícia SOUSA ${ }^{1}$; Laize Feitosa Solano NOGUEIRA ${ }^{2}$; Gerson Tavares PESSOA $^{1}$; \\ Matheus Levi Tajra FEITOSA ${ }^{3}$; Maria Acelina Martins CARVALHO ${ }^{4}$; Weber Leal MOURA ${ }^{5}$ \\ 1. Animal Science Post-Graduate, Federeal University of Piauí, Teresina, Piauí, Brazil. renata_patrycia@hotmail.com ; 2. Biologist, \\ Federal University of Piauí, Teresina, Piauí, Brazil; 3. Postdoctoral/PNPD-CAPES in Animal Science Post-Graduate Program, Federal \\ University of Piauí, Teresina, Piauí, Brazi;. 4. Department of Veterinary Morphophysiology, Federal University of Piauí, Teresina, \\ Piauí, Brazil; 5. Department of Morphology, Federal University of Piauí, Teresina, Piauí, Brazil.
}

\begin{abstract}
This present work describe the peripheral blood cell morphology from Chelonoids carbonaria. To do this were used ten animal specimens clinically healthy, six female and four male, submitted to peripheral blood collect by jugular vein. Blood was collected to prepare blood smears, without the use of anticoagulants. The slides were stained and analyzed microscopically to describe the cell morphology. The mature erythrocytes had an ellipsoid shape and a grain-free nucleus; immature ones were circular. The leukocytes, granulocytes and agranulocytes were also circular. The heterophils had cytoplasmic granules with various elongated shapes, and the eosinophils had a uniform round shape. The basophils had highly dense basophilic granules, stained in blue; the granules were irregularly arranged and also inside the nucleus. The lymphocytes were circular with a large circular nucleus. The thrombocytes were small, with basophilic staining and a small cytoplasm (the nucleus occupied almost the entire cell). The morphological results found in this study are consistent with cell types of other chelonians.
\end{abstract}

KEYWORDS: Blood. Cell Morphology. Tortoise. Chelonian. Reptile.

\section{INTRODUCTION}

Studies on the general biology of reptiles have been encouraged because of conservation issues, their use as pets and their economic potential (GIBBONS et al., 2000). The Chelonoidis carbonaria, or red-footed tortoise, is a reptile found in dry and warm regions by tropical zones of South America. In Brazil, they are common in the north, northeast and central-west regions (SILVA et al., 2008). Despite the laws to protect native wildlife, many specimens are illegally kept in captivity throughout the country (RIBEIRO et al., 2009).

Studies show that young chelonians and those in captivity are more susceptible to diseases and have a higher mortality rate, depending on environmental and hygiene conditions (SILVA et al., 2008; SANTOS; PEREIRA, 2011). Thus, the morphological description of the blood cells of this species is an important tool for the diagnosis and treatment of their health conditions, in both, their natural environment and in captivity (SAGGESE, 2009).

The hematological profile of reptiles can vary greatly due to environmental and physiological factors, or due to the stress caused during contention and blood collecting procedures (FALCE, 2009).
Thus, it is important to study and understand their particularities, in order to eliminate as much as possible these oscillations.

Reptiles are a heterogeneous group of vertebrates in terms of blood cell morphology. Unlike mammals, all reptiles possess erythrocytes, leukocytes and nucleated thrombocytes (GARCIANAVARRO et al., 1994). Generally, the blood of reptiles contains the following cells: erythrocytes, leukocytes (granulocytes: eosinophil, basophil and heterophil; agranulocytes: lymphocytes and monocytes) and thrombocytes (WORK et al., 1998). However, some authors believe there is a fourth type of granulocytic leukocyte: neutrophils (GARCIA-NAVARRO et al., 1994; GIRONS, 1970).

The main objective of this work was to analyze the morphology of peripheral blood cell from Chelonoidis carbonaria.

\section{MATERIAL AND METHODS}

Ten tortoises (Chelonoidis carbonaria) were used, six females and four males, from the Botanical Zoo, Teresina, Piauí, Brazil. The animals were previously identified, weighed, underwent clinic exam, blood profile and physical assessment. The 
animals were physically restrained and properly anesthetized using a combination of ketamine 3.16 $\mathrm{mg} / \mathrm{kg}$, (Vetnil, Louveira, Góias, Brazil) and xylazine $0.13 \mathrm{mg} / \mathrm{kg}$ (Virbaxyl 2\%, Virbac, São Paulo, Brazil), with a total dose of $3.29 \mathrm{mg} / \mathrm{kg}$. The anesthetics were intramuscularly administered into the right forelimb of animals as is usual for chelonians. After about 15 minutes, long enough for sedation, one (1) $\mathrm{mL}$ of blood was collected from the jugular vein of each animal after proper disinfection of the puncture site,using sterile and disposable $3 \mathrm{~mL}$ syringes, Descarpack, Medneedle, Itajaí, Santa Catarina, Brazil and 25x7 disposable needles, Méd Goldman , Manaus, Amazonas, Brazil, sterilized with ethylene oxide). For each animal, the blood was used to prepare 50 blood smears on slides previously cleaned with ethanolether solution (L.C. Comercial LTDA., CataguasesMinas Gerais, Brazil). There were 500 slides in total. The extensions were prepared immediately after collection, without the use of anticoagulants.

Blood extensions were analyzed

morphologically by Leishman, MayGrunwald/Giemsa e Leishman/Giemsa methods (Doles Reagentes, Chácara Retiro, Grande Goiânia, Brazil), stained from 6 to 10 minutes and analyzed using light microscopy (Olympus, CX 41, Olympus Corporation, Tokyo, Japan), at a $1000 \mathrm{x}$ magnification.

After the preparation of histological slides, a detailed morphological description of each cell type found was carried out. Photographic documentation was carried out using an image analyzer with a photomicrography system (VGA format, 1200 pixels) and digital camera (Sony W 200 Sony Electronics, Inc., San Diego, CA, United States) coupled to a light microscope (Nikon Eclipse E 200, Nikon Corporation, Tokyo, Japan).

This study was approved by the Ethics in Animal Experimentation Committee (CEEA) of the Federal University of Piauí (UFPI) under protocol No. 051/2010, in accordance with the norms of the Brazilian College for Animal Experimentation (COBEA).

\section{RESULTS}

Microscopic analysis of the extensions of stained peripheral blood showed the following cells: erythrocytes, thrombocytes, granulocytic leukocytes (heterophils, eosinophils and basophils), and agranulocytes (lymphocytes and monocytes) (Figure 1). Morphologically, the blood cells did not differ according to gender. Thus, the same cell types observed in females were seen in males.
The erythrocytes (Figure 1A) showed ellipsoid cell morphology with an abundant cytoplasm, that was lightly acidophilic, homogeneous, and without granules. Its oval nucleus was located in the center of the cell and had strong basophilic staining, and a very condensed chromatin, which indicates low intracellular metabolic activity. There were also young erythroyctes, which had spherical aspect, with a nucleus that mirrored the cell's shape and with a less condensed chromatin (Figure 1B).

The thrombocytes (Figure 1C) were small cells, with predominantly elliptical shape, although sometimes they had a less elongated shape. They presented basophilic staining and a cytoplasm that varied in volume, which was usually larger at the poles, thus compressing the nucleus; in some cases, however, there was a small cytoplasm. The elliptical nucleus and basophilic staining occupied almost the entire cell, and there was a relatively condensed chromatin. Agglutinates were observed from two to three cells, or clusters of dozens of cells.

The observed granulocytic leukocytes included large quantities of heterophils (Figure 1D), with several formats. They were easily identified because their large size. They had a dark pink/salmon color and dense cytoplasmatic granules, in circular, elongated or fusiform shapes. The nucleus was usually found in eccentric or peripheral position, with basophilic staining.

The eosinophils (Figure 1E) were large and spherical, similar to heterophils. However, their nucleus could be seen more easily, since it was peripheral and had basophilic staining without lobulations and condensed chromatin. The cytoplasm had spherical eosinophilic granules, which were uniformly distributed, with a clear pinkcolored tone due to the acidophilic character of their granules.

The basophils (Figure 1F) were spherical and usually found in smaller quantities (compared with the other granulocytic leukocytes) with areas of condensed chromatin. These were arranged irregularly inside the nucleus. When visible, the nucleus was slightly eccentric, and not lobulated. The cytoplasm was highly dense with basophilic granules, stained in blue. On the other hand, some of them had purple color.

The agranulocytic leukocytes, which were devoid of granules, included lymphocytes (Figure $1 \mathrm{G})$ in various sizes, which had a rounded shape and a regular contour, with a large spherical nucleus, condensed chromatin and dark-purple coloration. The cytoplasm ranged from small to medium, and was basophilic, with no granulations. 


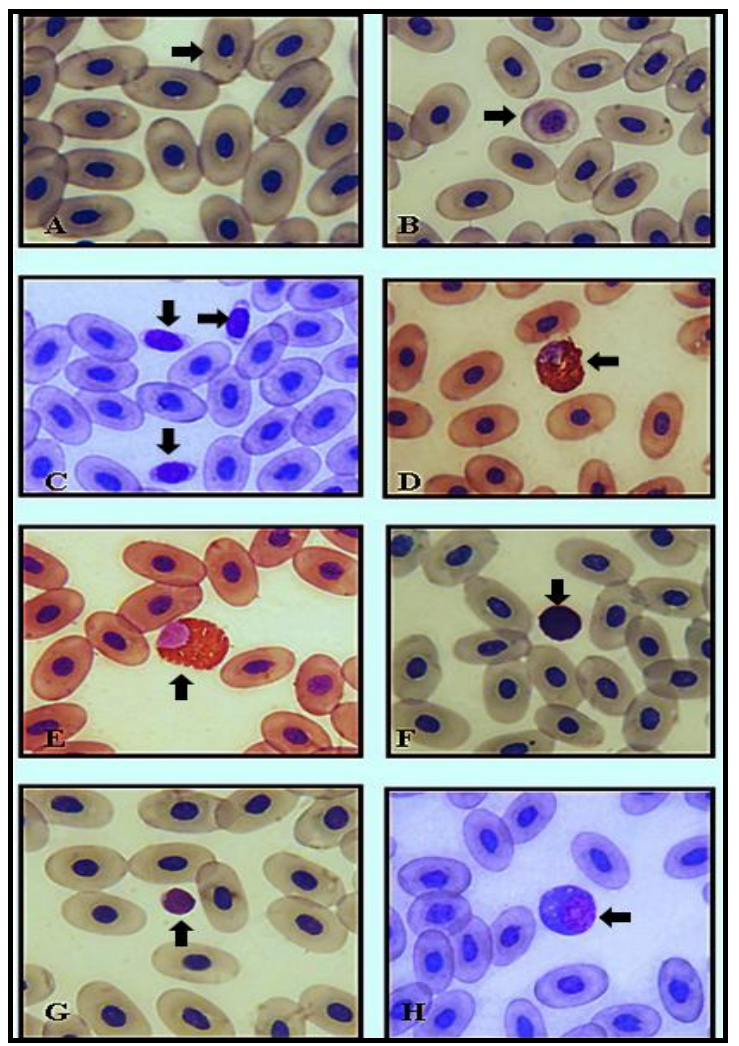

Figure 1. Peripheral Blood Photomicrographs. A) Mature erythrocyte (Leishman and Giemsa); B) Maturing erythrocyte (Leishman and Giemsa); C) Thrombocyte (May-Grunwald and Giemsa); D) Heterophil (Leishman); E) Eosinophil (Leishman); F) Basophil (Leishman and Giemsa); G) Lymphocyte (Leishman and Giemsa); H) Monocyte (May-Grunwald and Giemsa). Magnification X1000.

Monocytic lineage (Figure 1H) had spherical and bulky shape. Sometimes they had an irregular contour. The shape of the cell nucleus ranged from kidney-shaped to elliptical, and was located in the center or the periphery, with a loose chromatin and dark-purple staining. The cytoplasm was usually small and had an intense degree of basophilia.

\section{DISCUSSION}

The cell types found in blood smears of Chelonoidis carbonaria have also been observed in other chelonians, such as the green sea turtle (Chelonia mydas) (WORK et al., 1998; SANTOS et al., 2009), and the red-headed river turtle (Podocnemis erytrocephala) (SANTOS et al., 2011).

In the results obtained by Carvalho et al. (2006) in Squamata (Tupinambis merianae), there were no differences in the morphology of blood cells between genders, de igual modo, não foram verificadas diferenças nos tipos celulares de. Likewise, were not verified differences between blood cell constituents from gender of Chelonoides carbonaria.

According to Work et al. (1998) for turtles and Santos et al. (2011) for chelids, the most abundant cell types were erythrocytes, which had morphological features similar to the ones described in this study.

In their study of the Russian tortoise (Testudo horsfieldii), Shadkhast et al. (2010) observed that the thrombocytes had an elliptical shape with small cytoplasm and an elliptical nucleus. Studies of eosinophils have shown extensive morphological variation of these cells in different species, so it is difficult to characterize them based solely on morphology. However, it was possible to compare them with reports of other authors who also described them as large, spherical cells similar to heterophils, with a basophilic-stained peripheral nucleus, and cytoplasm with spherical and acidophilic cytoplasmic granules, (GIRONS, 1970; MOURA et al., 2005). These morphologic character were similar those observed in this study.

In their studies with Squamata (Tupinambis merianae), Carvalho et al. (2006) identified 
heterophils with acidophilic and basophilic granules, two basic shapes (cylindrical and spherical) and different sizes. In addition to these types, our study observed rod-shaped and fusiform granules.

The morphological features of Chelonoides carbonaria basophils resembled those described by Work et al. (1998) in their study on the green sea turtle (Chelonia mydas). They reported a dense, blue nucleus and a well-defined cytoplasm with numerous small basophilic granules that obscured the nucleus, as was found in this study.

Sachi et al. (2011) published an article on the morphology of leukocytes in 12 European lizards (Podarcis sicula, $P$. tiliguerta, $P$. melisellensis, P. bocagei, P. muralis, Algyroides nigropunctatus, Lacerta viridis, L. bilineata, $L$. trilineata, L. oxycephala, Timon lepidus and Zootoca vivipara). Similar to our study, they reported that the lymphocytes of European lizards, as in all other vertebrates, are mononuclear with a small azurophilic cytoplasm covering a narrow area around the nucleus. Monocytes were described as round cells that were larger than the erythrocytes. They presented moderate granular cytoplasmatic staining and were light pink. The nucleus may appear in the form of a "C", centrally positioned, and with violet pigmentation.

Studies by Santos et al. (2011) on the morphology of the blood cells of the red-headed river turtle (Podocnemis erytrocephala), and by Moura et al. (2005) on crocodilians (Caiman crocodilus yacare), identified erythrocytes with a typically oval format and elongated nucleus. Ugurtas et al. (2003) also reported this fact in some turtles in Turkey (Emys orbicularis Hellenica, Mauremys rivulata, Testudo hermanni hermanni and $T$. graeca ibera). The erythrocyte's nucleus had a dense chromatin with blue to dark purple staining.
Shadkhast et al. (2010) in the Russian tortoise (Testudo horsfieldii). The authors also reported the existence of thrombocytes of various shapes, ranging from ellipsoid to circular. The cytoplasm was scarce and the nucleus was oval or circular with dense chromatin, varying in color from pale blue to purple. Lymphocytes were circular, with a small and basophilic cytoplasm, surrounding a large, centrally positioned nucleus. The heterophils were described as having a predominantly circular shape with cytoplasm that was filled with pink-colored fusiform granules, and a spherical pale blue nucleus in a peripheral position. Moura et al. (2005) studied blood smears of the Caiman crocodilus yacare and observed eosinophils with specific cytoplasmic granules, which were round and uniformly distributed, and a small, condensed, peripheral nucleus. The basophils were round with intensely basophilic specific cytoplasmic granules and the nucleus was condensed, in a central position, occupying almost the entire cell.

Work et al. (1998) published an article about their observations on the morphology of green sea turtle (Chelonia mydas) cells. They found an oval shaped monocyte cell lineage with a purpleblue, circular and eccentric nucleus. The cytoplasm was slightly basophilic with irregular edges and had intracytoplasmic vacuoles of various sizes.

\section{CONCLUSIONS}

All blood cells of Chelonoidis carbonaria possess a cell nucleus. The most abundant elements of the blood are the erythrocytes, followed by heterophils, lymphocytes, monocytes, basophils and eosinophils. Furthermore, immature cells are observed in the circulating blood.

RESUMO: O presente estudo descreve a morfologia dos constituintes celulares do sangue periférico de Chelonoides carbonaria. Para tanto, 10 espécimes adultos, sendo seis fêmeas e quatro machos, clinicamente saudáveis foram submetidos à coleta de sangue periférico através da veia jugular. O sangue foi recolhido para preparar esfregaços sanguíneos, sem a utilização de anticoagulantes. As lâminas foram coradas e analisadas microscopicamente para descrever a morfologia da célula. Os eritrócitos maduros têm a forma elipsóide e apresentam núcleo central sem granulações; nas fases imaturas mostram-se arredondados. Os leucócitos, granulócitos e agranulócitos, também são circulares. Os heterófilos possuem grânulos citoplasmáticos com várias formas alongadas e nos eosinófilos são uniformes e arredondados. Os basófilos possuem grânulos altamente densos e basofílicos, corados em azul; os grânulos são dispostos de forma irregular e também no interior do núcleo. Os linfócitos são circulares com um grande núcleo circular. Os trombócitos são pequenos, com coloração basofílica e citoplasma escasso (o núcleo ocupa quase toda a célula). Os resultados encontrados nesta pesquisa são compatíveis com a morfologia encontrada nesses tipos celulares em outros quelônios.

PALAVRAS-CHAVE: Sangue. Morfologia celular. Jabuti. Quelônio. Réptil. 


\section{REFERENCES}

CARVALHO, R. L.; ANTONIAZZI, M. M.; JARED, C.; SILVA, A. M. J.; SANTOS, A. A.; EGAMI. M. I. Morphological, cytochemical, and ultrastructural observations on the blood cells of the reptile Tupinambis merianae (Squamata). Comparative Clinical Pathology, Harrow, v. 15, n. 3, p. 169-174, 2006.

http://dx.doi.org/10.1007/s00580-006-0628-0

FALCE, Maria Cecília Lopes Bittencourt. Hematologia de répteis. 2009. 49 f. Trabalho monográfico de conclusão do curso de Clínica Médica e Cirúrgica de Animais Selvagens e Exóticos. Universidade Castelo Branco. Instituto Quallitas de Pós Graduação, Campinas, 2009.

GARCIA-NAVARRO, Carlos Eugêncio Kantek. Manual de Hematologia Veterinária. 2. ed. São Paulo: Varela, 1994. $130 \mathrm{p}$.

GIBBONS, J. W.; SCOTT, D. E.; RYAN, T. J.; BUHLMANN, K. A.; TUBERVILLE, T. D.; MENTS, B. S.; GREENE, J. L.; MILLS, T.; LEIDEN, Y.; POPPY, S.; WINNE, C. T. The global of decline of reptiles, déjà vu amphibians. BioScience, Washington, v. 50, n. 8, p. 653-666, 2000. http://dx.doi.org/10.1641/00063568(2000)050[0653:TGDORD]2.0.CO;2

GIRONS, M. C. S. Morphology of the circulating blood cells. In: Gans C.; Parson T. (Ed.). Biology of the Reptilia. San Diego: Academic Press Inc, 1970. p. 73-91.

MOURA, W. L.; CARVALHO, V. A. L.; SANTOS, A. A.; EGAMI, M. I.; SILVA, M. R.; YAMAMOTO, M. Morphological and cytochemical observations of blood cells of Caiman crocodilus yacare (Daudin, 1802; Reptilia, crocodilia). Brazilian Journal of Veterinary Research and Animal Science, São Paulo, v. 36, n. 1, p. 319-326, 2005.

RIBEIRO, Matheus Marussi.; MARINHO, Márcia.; TAPARO, Cilene Vidovix.; TENCATE, Luciano Nery.; BALDASSO, Adônis Benvenuto. Análise da microflora gastrintestinal de Geochelones provenientes de cativeiro da região noroeste de São Paulo. In: CONGRESSO DE INICIAÇÃO CIENTÍFICA DA UNESP, 21, 2009, São José do Rio Preto. Anais... São José do Rio Preto, 2009. p. 3742-3745.

SACCHI, R.; SCALI, S.; CAVIRANI, V.; PUPIN, F.; PELLITTERI-ROSA, D.; ZUFFI, M. A. L. Leukocyte differential counts and morphology from twelve European lizards. Italian Journal of Zoology, Roma, v. 78, n. 4, p. 418-426, dec. 2011. http://dx.doi.org/10.1080/11250003.2011.568014

SAGGESE, M. D. Clinical approach to the anemic reptile. Journal of Exotic Pet Medicine, Philadelphia, v. 18, n. 2, p. 98-111, 2009. http://dx.doi.org/10.1053/j.jepm.2009.04.003

SANTOS, Gisele Junqueira.; PEREIRA, Rosa Elisabeth Peres. Levantamento de Aspergillus fumigatus e Strongyloides $s p$. em jabutis mantidos em cativeiro no bosque municipal Dr. Belírio Guimarães Brandão Zoológico Municipal da cidade de Garça-SP. Revista Científica Eletrônica de Medicina Veterinária, Garça, v. 9, n. 16, p. 1-29, jan. 2011.

SANTOS, Márcio Quara Carvalho.; OLIVEIRA, Adriano Teixeira.; SALES, Rejane Souza Aquino.; CARMO, Iracimar Batista.; TAVARES-DIAS, Marcos.; AFFONSO, Elisabeth Gusmão.; MARCON, Jaydione Luiz. Caracterização morfológica das células sanguíneas da irapuca (Testudines, Podocnemididae) do médio Rio Negro, Amazonas. In: CONGRESSO BRASILEIRO DE ENGENHARIA DE PESCA (COBEP), 17, 2011, Belém. Anais... Belém, 2011. p. 1-4.

SANTOS, M. R. D.; FERREIRA, L. S.; BATISTOTE, C.; GROSSMA, I. A.; BELLINI, C. Valores hematológicos de tartarugas marinhas Chelonia mydas (Linnaeus, 1758) juvenis selvagens do Arquipélago de Fernando de Noronha, Pernambuco, Brasil. Brazilian Journal of Veterinary Research and Animal Science, São Paulo, v. 46, n. 6, p. 491-499, nov./dez. 2009. 
SHADKHAST, M.; SHABAZKIA, H. R.; SADEGH, A. B.; SHARIATI, S. B.; MAHMOUDI, T.; FARD, M. S. The Morphological Characterization of the Blood Cells in the Central Asian Tortoise (Testudo horsfieldii). Veterinary Research Forum, v. 1, n. 3, p. 134-141, dec. 2010.

SILVA, Ana Elisa Pereira.; PEREIRA, Danielle Monteiro.; VELHO, Nádia Maria Campos. Análise parasitológica em quelônios de cativeiro. In: ENCONTRO LATINO AMERICANO DE INICIAÇÃO CIENTÍFICA E VII ENCONTRO LATINO AMERICANO DE PÓS-GRADUAÇÃO, 12, 2008, São José dos Campos. Anais... São José dos Campos: Universidade do Vale do Paraíba, 2008. p. 1-4.

UGURTAS, I. H.; HIKMET, S. Y.; SEVINC, M. Erythrocyte size and morphology of some tortoises and turtles from turkey. Zoological Studies, Taiwan, v. 42, n. 1, p. 173-178, oct. 2003.

WORK, T. M.; RASKIN, R. E.; BALAZS, G. H.; WHITTAKER, S. D. Morphologic and cytochemical characteristics of blood cells from Hawaiian green turtle. American Journal of Veterinary Research, Schaumburg, v. 59, n. 10, p. 1252-1257, oct. 1998. 